\title{
Empirical analysis of Brazilian banks' capital buffers during the period 2001-2011*
}

Vinícius Cintra Belém

Banco do Brasil, Brasília, DF, Brazil

Ivan Ricardo Gartner

Universidade de Brasília, Programa de Pós-Graduação em Administração, Brasília, DF, Brazil

Received on 12.16.2013 - Desk acceptance on 01.27.2014 - $4^{\text {th }}$ version accepted on 12.29.2015.

\section{ABSTRACT}

International literature indicates that the capital buffers held by banks result notably from the trade-off that exists between the cost of holding capital, adjustment costs, and bankruptcy costs, which all have a direct impact on banks' capital structures. The aim of this paper is to study the degree of sensitivity of Brazilian banks' capital buffers to the determining factors established in the literature, by using a sample of 121 banks, covering the period from 2001 to 2011. The empirical analysis that was carried out found that there was a significant cost of . adjusting capital buffers for the Brazilian banks. At the same time, bankruptcy cost indicated a positive relationship between risk profile and capital buffers, while the cost of holding capital did not exhibit statistical significance in the analysis.

Keywords: banking institutions, banking risk, regulatory capital buffers, dynamic panel data. 


\section{INTRODUCTION}

Banking institutions play a fundamental part in how economic systems operate, especially due to their role as financial intermediaries. In this role, banking institutions capture the resources of agents with surpluses (investors) in order to subsequently transfer them to agents with deficits (assignees of credit). In exercising this role of intermediation between investors and receivers of credit, banks are exposed to various types of risks, which can weaken their financial situation. In order to avoid one bank's financial problems compromising the whole system of financial intermediation in a market, regulatory bodies require banks to hold capital reserves in order to face the risks inherent to their business, aiming to maintain a safe environment for the financial system.

Studies carried out in the international field, among which those of Jokipli and Milne (2008, 2011), and Stolz and Wedow (2011) stand out, have found empirical evidence that most banks have held levels of capital in reserves above the minimum amount required by regulatory bodies. This difference between the capital reserve held by banks and the level of regulatory capital, which is called the regulatory capital buffer, constitutes the focus of this study. It aims, specifically, to analyze whether the factors proposed by the literature as determinants for holding regulatory capital buffers are also relevant in the area of Brazilian banking institutions.

According to Alencar (2011), capital buffer theory, which favors holding capital above the minimum level required by regulators, has gained popularity among theories which study capital requirements and the adjustment of banks' portfolios.

Estrella (2004) and Ayuso, Perez, and Saurina (2004) propose that the amounts of capital buffers to be held by banks are given by the trade-off between three main factors: the cost of adjusting capital; the cost of holding capital; and the cost of bankruptcy.

The cost of adjusting capital derives from the costs generated by raising new funds to recompose capital levels. For Rime (2001), if banks fall below the regulatory minimum, they can suffer penalties imposed by regulatory agencies, or they might even have to cease operations. Gropp and Heider (2010) state that, as a result of this risk and the high cost of raising capital in the short run, banks opt for holding capital buffers.

The cost of holding capital affects decisions regarding the amount to be held by banks, since such capital will not be remunerated, thus penalizing the opportunity cost of shareholders' financial resources. Therefore, the higher the cost to banks of holding this capital, the smaller the capital buffer to be held should be.

To these two costs can be added bankruptcy cost, which refers to the cost that an extrapolation of the minimum capital ratio can result in from regulators, or to the cost of not returning credit loaned by banks to their clients.

As well as these three main factors, various others discussed in the literature can affect a bank's decisions to hold capital above the regulatory minimum required, such as the size of the bank, the country's economic cycles, the demand for credit, merger and acquisitions operations, and banking regulation, among others. Thus, banks, at the time they outline their capital structure policies, aim to maximize the return on existing capital, considering the trade-off between the three main types of costs mentioned previously and other factors that can affect their capital structures.

Fonseca and González (2010) analyzed whether these three costs, as well as other variables, determined banks' capital buffers in around 70 countries, including 56 Brazilian banks, between 1995 and 2001. After this period, there have been few studies focused on the Brazilian case, which motivated the development of this paper. Thus, this study aims to contribute to the state of current knowledge regarding the factors that have influenced Brazilian banks' decisions when defining their capital structures, and, consequently, in determining capital buffer amounts, given that this is a relevant issue due to it involving an economic sector that is more and more competitive in a more intense regulatory environment. The study analyzed the behavior of 121 Brazilian banks between 2001 and 2011, a period in which there was great change in the architecture of the international financial system, above all after the crisis triggered in July 2007 in the United States.

The article is organized in the following way: the first section presents the motivation and reason for the study; the second presents a brief breakdown of banking regulations and the state of current knowledge from the literature on capital buffers. In section 3, the methodological procedures for the study are described, notably the variables used, and specification of the econometric model. In section 4 , an empirical analysis is carried out, and section 5 presents the article's conclusions.

\section{BANKING REGULATION AND REGULATORY CAPITAL}

In 1988, the Bank of International Settlements (BIS) met to create an agreement (Basel I) that set the minimum amount of capital that banks should hold, aiming to stabilize the international financial system. Subse- quently, in 2004 and 2006 (Basel II), the Basel Committee issued new guidelines, detailing how banks should measure their risks (Pillar I), and how they should manage their levels of capital in the face of the risks they 
were exposed to (Pillar II).

In order to verify banks' solvency levels, regulatory bodies use the Basel ratio, which is an indicator that verifies whether banks capital (Reference Equity) is sufficient to cope with the risks that are inherent to their operations, which are shown in the form of Required Reference Equity (RRE). This verification is related to the context of Pillar I of Basel II, which determines institutions' minimum capital requirements. The Basel ratio defined by the Basel Committee is $8 \%$ and that adopted by the Brazilian Central Bank (BACEN) since 1997 has been $11 \%$.

For regulatory purposes, during the period covered by the study, bank capital was divided into two levels. Level I capital is where banks' base capital lies. For Glantz (2007, p. 338), level I capital is the most valuable to banks. The main components that can be classified into this level are ordinary shares, perpetual preferred shares, characterized as non cumulative, and retained earnings, where the majority of reserves and the premiums paid in the acquisition of investments should be excluded.

As well as level I capital, regulators also consider other instruments as being capital for coping with the risks banks face, known as level II capital. Some shareholder equity accounts that have not composed level I capital are included in this capital, as well as debt instruments that do not form part of shareholder equity, such as hybrid capital and debt instruments, and subordinated debt instruments.

According to Vallascas and Hagendorff (2013), the regulatory capital required by banks serves to increase certainty and solidity, holding sufficient capital to cope with the risks that their assets might be exposed to.

\subsection{Capital Buffers}

For Peura and Keppo (2006), the capital structure chosen by banks is, in essence, defined by their risk management decisions, since banks do not use capital as a form of financing, but rather, as a buffer against their assets exposed to risk, which need to be managed in order to satisfy a minimum capital required with relation to possible future adversities. According to the authors, it is implicit that violation of this minimum capital value results in costs for banks, or a need for restrictions on their portfolios of assets, or new capitalization. Elizalde and Repullo (2007) also add support to this idea, claiming that the non observation of a regulatory minimum could even result in banks closing, prompting capital levels to be held that are above the minimum required.

Shrieves and Dahl (1992) relate some factors that affect the capital held by banks, such as bankruptcy costs, caused by the exposure of their assets to risk, and management aversion to risk, originating from shareholder pressure over managers to hold lower leverage. The authors also mention the need to observe the minimum capital level required by regulators and regulatory costs as factors that affect capital held.
As well as the risks and costs that banks can incur in not managing to hold the minimum capital required, they also need to uphold a capital structure compatible with market expectations and which allows them to exploit future investment opportunities, having sufficient capital available to grant new loans and carry out the investments demanded by the market (Berger, Herring, \& Szegö, 1995; Jokipii \& Milne, 2008). Moreover, Estrella (2004) highlights that banks' capital structures should take optimization of their capital into account, considering all costs and expected returns.

Estrella (2004) and Ayuso et al. (2004) stress that banks' decision models with regards to their capital is the result of the trade-off of three different types of costs - the cost of holding capital, the cost of bankruptcy, and the cost of adjustment - and, as they are obliged to hold the minimum capital determined by regulators, their decisions can only occur in relation to the size of the buffer to be held.

For Ayuso et al. (2004), holding capital has a direct cost for banks, because, given information asymmetry, this source of funds is more expensive than other financing options. In the pecking order theory described by Myers (1984), retention of earnings by companies is the first option for financing, since funds generated internally do not have transaction costs.

Given these factors, retention of earnings is one of the ways that banks use most to increase their capital buffers, implying that returns have a positive impact on them. On the other hand, Stolz and Wedow (2011) claim that high returns can also be interpreted as the ability of a bank to maintain this level of profitability, meaning these returns are subsequently incorporated into the bank's capital, sustaining the growth of their assets weighted by risk. Thus, a negative impact of returns on capital buffers can also be expected.

In relation to bankruptcy cost, holding a capital buffer reduces the likelihood of bank failure, loss of reputation, and the costs of resulting legal action (Ayuso et al., 2004). In the concept of bankruptcy cost, the cost of failure is also considered, which contemplates the likelihood of losses resulting from the investments made by banks. For Bikker and Metzmakers (2004), this cost depends specifically on the risk profile of each bank.

The concept of bankruptcy cost also considers risks of non compliance with the regulatory minimum required and the costs resulting from this, such as restrictions that can be imposed by regulators (Ayuso et al., 2004).

The risks a bank is exposed to can be measured in different ways, but, according to Jokipii \& Milne (2011), this measurement is not simple and each proxy used exhibits a limitation. Basically, an ex ante measurement of risks can be considered, anticipating their effects, or an ex post one, observing the effects after their occurrence.

Bikker and Metzemakers (2004), and Boucinha and Ribeiro (2007), observe that when an ex ante measurement of risk is used, a positive relationship between a 
bank's capital and the risk from its portfolio of investments is expected, given that banks with greater risk should hold more capital. For Ayuso et al. (2004), and Boucinha and Ribeiro (2007), ex post measurement of risk exhibits a negative relationship between a bank's capital and the risk from its portfolio of investments. This negative relationship can be explained by the consumption of capital that will occur when risk materializes, in the form of losses or through provisions that affect bank capital. For Jokipii and Milne (2008), risk measured ex post should also exhibit a positive relationship between a bank's capital and the risk from its portfolio of investments, since ex post risk also demonstrates the risk profile of banks.

In relation to adjustment cost, Ayuso et al. (2004) argue that changes in bank capital levels incur costs, and the main cost of adjustment is related to the problem of information asymmetry. As banks have a greater level of information than the market, they require higher remuneration to make recomposing their capital possible. Stolz and Wedow (2011) also argue that banks cannot make instantaneous adjustments in their capital or in their risk (portfolio of investments). As capital rearrangements or sales of or changes in investments require some time to be carried out, banks need to hold capital buffers. Thus, adjustment cost should exhibit a positive relationship with bank capital.

Jokipii and Milne (2008) argue that, among the factors that affect capital buffers, the one that stands out most is bank size. Stolz and Wedow (2011) show some cases in which the size of banks can affect capital buffers. Larger banks can have greater investment and diversification opportunities, thus presenting a lower likelihood of suffering a negative shock in their capital, with them being able to hold smaller buffers as insurance for this risk. For Tabak, Li, Vasconcelos, and Cajueiro (2013), the use of this variable in studies regarding financial institutions is important given economies of scale, and can explain the individual characteristics of each bank.

Another reason is that in the case of financial crises, there is a greater likelihood that large banks would be rescued by governments, avoiding a potential systemic effect. This rescue of large banks by governments is called "too big to fail" (Berger et al., 1995; Rime, 2001; Ayuso et al., 2004; Lindquist, 2004; Jokipii \& Milne, 2008; Araújo, Jorge \& Linhares, 2008).

A great amount of the literature regarding capital buffers addresses the influence of the economic cycle on the behavior of banks' capital buffers (Ayuso et al., 2004; Lindquist, 2004; Ferreira, Noronha, Tabak \& Cajuerio, 2010; Stolz \& Wedow, 2011). Such studies have aimed to observe whether the behavior of capital buffers was pro-cyclical or counter-cyclical. If the behavior was pro-cyclical, it is expected that during economic growth there would be an increase in the volume of loans, without sufficient funds being raised to counter the risks on them, causing reductions in capital buffers. If the behavior was counter-cyclical, it is expected that, during economic growth, there would be an increase in the volume of loans, with more, or at least enough, funds being raised to counter the risks on the loans, causing an increase or maintenance of capital buffers.

In a way, one of the reasons for seeking the relationship between the economic cycle and capital buffers lies in that fact that, with growth in the economy, banks grant more credit, possibly affecting their capital buffers. Thus, another variable that can have an influence over banks' capital buffers is borrowers' demand for credit. When this demand for credit increases, and banks supply it through loans, assets exposed to risk increase, thus resulting in the consumption of banks' capital buffers.

\section{STUDY METHODOLOGY}

\subsection{Population and Sample}

The period covered in this study was from the 1st quarter of 2001 to the 4th quarter of 2011, amounting to 44 quarters in total. Some filters were used in order to improve the quality of the data, such as using banks that presented a greater historic series than 15 months and excluding those that already suffered intervention or liquidation by $B A C E N$, those that were under investigation for indications of fraud in their financial statements, and those that exhibited volatility in their capital buffer volatility coefficients greater or equal to 2 . Thus, the sample used in this study comprised 121 banks.

The data employed for calculating the dependent variable and the majority of explanatory variables was obtained from the " 50 Biggest Banks and the Brazilian Financial System Consolidated Report" (2012), available from the BACEN website. The explanatory variable Variation in GDP, used as a proxy for the economic cycle, was obtained from the Brazilian Institute of Geography and Statistics (IBGE) website. The dummy variable Mergers and Acquisitions was obtained from the Mergers and Acquisitions report from the company RISKbank, which carried out a survey of these operations over the period from 1998 to 2012, based on information divulged in the press.

\subsection{Variables Used in the Study}

In accordance with the literature review regarding 
the factors that influence the capital buffers held by banks, and by means of analysis of the variables used in studies related with the issue, we selected variables related to the three main costs that affect capital buffers, which are the cost of holding capital, the cost of bankruptcy, and the cost of adjustment, as well as other control variables that can alter their behavior.

\subsubsection{Capital buffers}

The dependent variable in the study is the additional value of capital that banks hold above the regulatory minimum required by $B A C E N$. As seen in previous sections, during the period covered by the study, from 2001 to 2011, the Basel ratio (BR) required of Brazilian banks was $11 \%$.

Thus, capital buffers were defined as the excess capital from the period, calculated by the BR presented by banks in the period, minus the regulatory BR (11\%), and divided by the regulatory BR (11\%), thus resulting in the percentage of excess capital over the regulatory minimum required. This capital buffer calculation was also used in studies by Ayuso et al. (2004), Fonseca and González (2010), and Tabak, Noronha, and Cajueiro (2011).

\subsubsection{Adjustment cost}

Adjustment cost is represented by the speed with which banks adjust their capital between two periods. Thus, adjustment cost is represented by banks' capital buffers in the previous period $(t-1)$. For this variable a positive sign is expected, and that its coefficient would be greater than zero. Other studies also used this same proxy, such as those by Ayuso et al. (2004), Boucinha and Ribeiro (2007), Jokipii and Milne (2008), Fonseca and González (2010), and Silva and Divino (2012).

When the coefficient approaches zero, this means that banks have a low adjustment cost, and consequently, capital buffers in period $t$ depends little on capital buffers in period $t-1$, showing that banks have the agility or ability to make large changes in their capital buffers. When the coefficient moves away from zero, this means that banks have a higher adjustment cost, and consequently, capital buffers in period $t$ depend a lot on capital buffers in period $t-1$, meaning banks having little agility or a lack of ability to make large changes to their capital buffers.

\subsubsection{Cost of holding capital}

As discussed in section 2.1, one of the ways that banks use most in order to increase their capital buffers is the retention of earnings. There is demand on the part of bank owners for remuneration on the capital they hold, with the RoE (Return on Equity) variable being used as a proxy for the cost of holding equity, which is calculated as the ratio between net profit and average net equity. Other studies also use this proxy, such as Ayuso et al. (2004), and Jokipii and Milne (2008).

If the RoE variable represents a good proxy for the cost of holding shareholder capital, a negative sign should be found. A negative sign can also be found if banks consider higher returns to mean an ability to continue generating high returns, thus allowing a lower capital buffer to be held. According to Merhan and Thakor (2011), banks may prefer to use earnings to recompose their capital; thus, a positive result for the RoE variable may also be expected. Thus, in the study an ambiguous sign for the RoE variable was expected.

Another variable that is used to express earnings retention by banks in order to increase capital buffers is Volatility of Results. Lindquist (2004) argues that banks can increase their capital buffers by means of retained earnings, but this option becomes uncertain when results exhibit high variations. Thus, it is expected that the Volatility of Results variable would exhibit a positive sign in relation to capital buffers. The variable consists of the natural logarithm of the standard deviation in net profit from the past 12 periods, in a similar way to that used by Lindquist (2004).

\subsubsection{Bankruptcy cost}

According to Rime (2001), the definition and measurement of banking risk is quite problematic, with the literature making various different suggestions. For Stolz and Wedow (2011), the main determinant of risk for traditional banks is credit risk. According to $B A C E N$ 's Financial Stability Report (2012), the main component of RRE risk in the Brazilian Financial System is the amount of credit risk, which represented 91\% of RRE in December 2011. Thus, the variables used as a proxy for bankruptcy cost are related to credit risk, such as Risk, Weight of Credit Portfolio, and Liquidity.

The Risk variable is defined as the amount of allowance for loan and lease losses (ALLL) on a total credit portfolio. The amount of ALLL represents the values already accounted for, according to the criteria of Resolution 2.682/1999 of the Brazilian Monetary Council. According to this resolution, the risk of operations should be calculated taking into account client and operation characteristics, and the length of delay, among other factors. Thus, as this variable represents the credit risk profile of a bank's credit portfolio, a positive sign was expected, given that banks with worse risk profiles (higher provisions) should hold higher capital buffers. This variable is proposed by the authors, adapting the NPL (non performance loan) risk/credit portfolio proxy used in papers by Ayuso et al. (2004), Stolz and Wedow (2005), and Ferreira et al. (2010).

The Weight of Credit Portfolio variable is defined as total credit operations with commercial lease operations over total bank assets. Thus, the variable expresses the proportion of total assets invested in a credit portfolio. For Bikker and Metzemakers (2004), a lower percentage for this variable can indicate that a bank invests more in low risk operations and loans to the government, demonstrating a lower risk profile 
and configuring an ex ante measurement of risk. Given this, a positive sign was expected for the variable.

The Liquidity variable is defined as total funds available, plus interbank investments, plus bonds and securities, and derivative financial instruments, over total bank assets. With this, the variable expresses the proportion of total assets that are invested in securities, which mostly have higher liquidity than banks' credit operations. As these assets have very low exposure to risk, regulators require that little or no capital be held, which results in lower consumption of banks' capital buffers, and a positive sign for this variable is thus expected. It was also used in studies by Stolz and Wedow (2011), Tabak et al. (2011), and Silva and Divino (2012).

\subsubsection{Size}

As a proxy for bank size the Size variable was used and two dummy variables, Large Banks and Small Banks.

The Size variable is defined by the natural logarithm of total bank assets. For this variable a negative sign was expected, since the bigger a bank, the lower its capital buffer should be. This variable was also used in studies by Stolz and Wedow (2011), Tabak, Fazio, and Cajueiro (2011), and Silva and Divino (2012).

The dummy variable Large Banks is defined by value 1 when a bank belongs to the largest $10 \%$ (ten percent), in terms of total assets, included in the sample for the period, and zero if it does not belong to this group. For this variable a negative sign was expected.

The dummy variable Small Banks is defined by the value 1 when a bank belongs to the smallest $30 \%$ (thirty per cent), in terms of total assets, belonging to the sample for the period, and zero if it does not belong to this group. For this variable a positive sign was expected. These dummy variables were also used in studies by Ayuso et al. (2004) (originally, Ayuso et al. used 10\% for the small banks), and Jokipii and Milne (2008).

\subsubsection{Economic cycle/demand for credit}

The economic cycle can affect capital buffers in two ways, with there being a positive impact when their behavior is counter-cyclical, and a negative impact when their behavior is pro-cyclical.

The variable used as a proxy for the economic cycle was Variation in GDP, calculated by the variation in nominal GDP for a period in relation to the previous one, with an ambiguous sign being expected. This variable was also used in studies by Ayuso et al. (2004), Lindquist (2004), and Stolz and Wedow (2011).

The demand for credit, when met by banks, results in a greater number of loans being granted, causing an increase in their assets weighted by risk. Thus, the demand for credit consumes capital buffers, causing their decrease. The variable used as a proxy for the demand for credit was Variation in Credit, defined by the variation of total credit operations and leasing operations for a period in relation to the previous one. For this variable a negative sign was expected, and it was also used in studies by Ayuso et al. (2004), and Jokipii and Milne (2008).

\subsubsection{Control variables}

Other variables were used in the study to verify whether they affect the capital buffers held by banks. These were the dummy variables Control, Origin, Small Portfolio, Mergers, and Basel II.

The dummy variable Control is defined by the value 1 when a bank is controlled by public federal or state institutions and zero if it is controlled by private institutions. According to Medeiros and Pandini (2008), the nature of the shareholder control of a banking institution causes implications with regards to strategic decisions, management style, and accountability, among other aspects. As a result of this, this variable was used to verify the influence bank control has over capital buffers, with an ambiguous sign being expected.

The dummy variable Origin is defined by the value 1 when a bank is controlled by foreign institutions and zero if it is controlled by Brazilian institutions. As the Basel II principles were implemented in other countries before BACEN adopting them, it was expected that banks under foreign control would have a more active behavior with regards to managing their risks and their capital. Thus, a positive sign was expected for this variable. No other studies were found which have used this variable.

The dummy variable Small Portfolio is defined by the value 1 when a bank has less than 20\% (twenty percent) of its total assets composed of credit portfolio, and zero is it has more than $20 \%$ (twenty percent). According to Silva and Divino (2012), banks with this characteristic exhibit a low level of financial intermediation activity, basically operating as a treasurer to their economic conglomerates and having higher capital buffers. Thus, a positive sign for this variable was expected.

The dummy variable Mergers is defined by the value 1 in a period in which a bank actively participated in a merger and/or acquisition process, and zero in other periods. When a bank leads a merger and/or acquisition it incorporates all of the assets and liabilities of the other institution into its consolidated balance sheet. Thus, in the merger and/or acquisition period, a bank's risk-weighted assets will be high, causing a reduction in its capital buffer. Thus, a negative sign was expected for this variable. It was also used in studies by Stolz and Wedow (2005), and Boucinha and Ribeiro (2007).

The dummy variable Basel II is defined by the value 1 from the 3 rd quarter of 2008, and zero in preceding quarters. As previously discussed, with the implementation of the Basel II accord, banks had to streamline their management of risks and capital. Thus, it was ex- 
pected that, since BACEN's adoption of the Basel II accord, banks would hold greater capital buffers, with a positive sign thus being expected for this variable. No other studies were found that have used this variable.

The set of variables described is detailed in Table 1, which also contains the respective signs expected.

Table 1 Expected signs for the dependent variables

\begin{tabular}{|c|c|c|}
\hline Variable & Expected Sign & Description \\
\hline Adjustment Cost & Positive & Capital buffer of bank in previous period $(t-1)$ \\
\hline RoE & Ambiguous & Net profit over average net equity \\
\hline Volatility of Results & Positive & Natural log of standard deviation in net profit in last 12 periods \\
\hline Risk & Positive & ALLL over total credit portfolio \\
\hline Weight of Credit Portfolio & Positive & Total credit operations over total assets \\
\hline Size & Negative & Natural logarithm of total bank assets \\
\hline Large Banks & Negative & Bank belongs to the largest $10 \%$ of banks (dummy) \\
\hline Small Banks & Positive & Bank belongs to the smallest $30 \%$ of banks (dummy) \\
\hline Variation in GDP & Ambiguous & Variation in nominal GDP between periods \\
\hline Variation in Credit & Negative & Variation in volume of credit operations between periods \\
\hline Origin & Positive & Bank controlled by foreign institutions (dummy) \\
\hline Small Portfolio & Positive & $\begin{array}{l}\text { Bank holds less than } 20 \% \text { of total assets composed of } \\
\text { credit portfolio (dummy) }\end{array}$ \\
\hline Mergers & Negative & Bank actively participated in merger and/or acquisition process (dummy) \\
\hline Basel II & Positive & Period since 3rd quarter of 2008 (dummy) \\
\hline
\end{tabular}

Source: Developed by the authors.

In Table 2, the descriptive statistic for each of the variables used in the study can be observed.

Table 2 Descriptive Statistic for Variables Used in the Study

\begin{tabular}{|c|c|c|c|c|c|c|}
\hline Variables & Frequency & Average & Standard Deviation & VC & Minimum & Maximum \\
\hline Buffer & 4,670 & 2.5212 & 6.1603 & 2.4434 & -2.1309 & 112.0055 \\
\hline RoE & 4,653 & 0.0289 & 0.1163 & 4.0173 & -3.1761 & 2.2325 \\
\hline Risk & 4,670 & 0.0612 & 0.0963 & 1.5732 & 0.0000 & 1.0000 \\
\hline Size (Assets in $\mathrm{R} \$ 1,000$ ) & 4,670 & $19,067,706$ & $74,457,786$ & 3,9049 & 12,424 & $935,009,463$ \\
\hline GDP Growth & 4,670 & 2.8231 & 15.4400 & 5.4691 & -0.9908 & 107.0289 \\
\hline Volatility & 4,670 & 9.0960 & 2.0265 & 0.2228 & 0.0000 & 14.6346 \\
\hline Liquidity & 4,670 & 0.4141 & 0.2425 & 0.5856 & 0.0001 & 0.9921 \\
\hline Weight of Portfolio & 4,670 & 0.3885 & 0.2693 & 0.6932 & 0.0000 & 1.0344 \\
\hline
\end{tabular}

Note. VC is the variation coefficient (standard deviation/average).

Source: Developed by the authors.

Table 2 contains the descriptive statistics for the behavior of the variables in the study, with the exception of the dummy variables, in the sample of 121 in the period from 2001 to 2011.

The most dispersed behavior variables in the sample were portfolio growth, GDP growth, RoE, size (assets measured in monetary units), the regulatory capital buffer itself, and risk, which exhibited higher variation coeffi- cients. This dispersion can be explained by the fact that the Brazilian banking sector is concentrated, where a small number of banks accumulate a greater volume of business and assets. The other variables in the study - volatility, liquidity, and weight of portfolio - exhibited less dispersed behavior, which can be explained by the fact that some company decisions were taken in convergence with regulatory body rules. 


\subsection{Econometric Modeling}

The econometric model used to analyze the behavior of banks' capital buffers during the period analyzed was one with dynamic panel data, given the presence of a lagged dependent variable being an explanatory variable.
The estimation for the model was carried out as defined in Equation 1, based on the study carried out by Ayuso et al. (2004), in which capital buffers are determined by the trade-off between the costs of holding capital, bankruptcy, adjustment, and other variables that may have an influence over them.

$$
B U F_{i, t}=\beta_{0} B U F_{i, t-1}+\beta_{1} R O E_{i, t}+\beta_{2} R I S K_{i, t}+\beta_{3} \omega_{i, t}+\varepsilon_{i, t}
$$

where $\mathrm{BUF}_{\mathrm{i}, \mathrm{t}}$ represents the capital buffer, $\mathrm{BUF} \mathrm{F}_{\mathrm{i},-1}$ represents the adjustment cost, $\mathrm{ROE}_{\mathrm{i}, \mathrm{t}}$ represents the cost of holding capital, RISK ${ }_{i, t}$ represents the cost of bankruptcy, $\omega_{i, t}$ represents other factors that may affect the capital buffer, as mentioned previously, and $\varepsilon_{\mathrm{i}, \mathrm{t}}$ represents the com- posed error term.

The parameters in Equation 1 were estimated by the Generalized Method of Moments (GMM), in accordance with the procedures from Arellano and Bover (1995), and Blundell and Bond (1998).

\section{RESULTS AND ANALYSES}

\subsection{Econometric Models Analyzed}

The estimation of the econometric model represented in Equation 1 was carried out in four models, each using a different set of variables, but all of which converge with the support theory arguments. This procedure was adopted as a way of verifying the general model's (Equation 1) degree of robustness with regard to the selected variables. The result found for the four models can be observed in Table 4 .

Model 1 was based on the theoretical model from Ayuso et al. (2004), in which capital buffers are determined by adjustment cost, the cost of holding capital, bankruptcy cost, bank size, and the economic cycle.

In Model 2, the economic cycle, represented by the Variation in GDP variable, is substituted by the demand for credit in the economy, represented by the Variation in Credit variable. As the use of the economic cycle seeks to capture the behavior of capital buffers for all of the banks in the sample, without considering their particular features, given that the Variation in GDP variable only changes with time and not for individuals (time series), the demand for credit in the economy was used, represented by the Variation in Credit variable, which considers the particular features of a bank during the whole process.

In Model 3, the proxy used to verify the influence of bank size on capital buffers changed, with the Size variable substituted by the dummy variables Large Bank and Small Bank. The intention behind this alteration in the model was to observe the specific behavior of these two bank characteristics.

Model 4 used Model 2 as a base, adding the other variables presented previously, to observe the results altogether, and not using only the dummy variables Large
Bank and Small Bank.

\subsection{Estimating Procedures and Tests}

The estimation of the parameters used in the dynamic panel model determined by the GMM System method in two stages, based on Arellano and Bover (1995), and Blundell and Bond (1998), which is an extension of the original model from Arellano and Bond (1991). Estimation of the model in two stages is asymptotically more efficient that in one stage, but can cause bias in the standard errors in small samples (Stolz \& Wedow, 2011; Silva \& Divino, 2012). To correct this bias in the standard errors the correction matrix proposed by Windmeijer (2005), known as the robust WC estimation, was used.

The autocorrelation test for the error terms indicated a first order autocorrelation, rejecting the null hypothesis of absence of autocorrelation for all of the models used, and indicated non rejection of the null hypothesis for second order autocorrelation for all of the models. The Sargan test, used to test the validity of the variables used as instruments (BUFt-1, RoE, and RISK), did not allow for rejection of the null hypothesis that all of the instruments are valid, thus indicating that the instrumental variables used are valid. The results of the two tests demonstrated the validity of the specification and of the instruments used.

Statistical models that use time series presuppose that the underlying time series is stationary. To test the stationarity of the capital buffer variable, the Im, Peraran, and Shin (IPS) unitary root test, proposed by Im, Peraran, and Shin (2003), was carried out, which according to Baltagi (2008, p. 278) makes it possible to identify the heterogeneity coefficients between indi- 
viduals by means of a procedure based on the unitary root test for the individual average. The IPS considers it a null hypothesis that all of the panel set has a unitary root, with $\mathrm{H}_{0}: \rho_{\mathrm{i}}=0$ for all of the individuals and, as an alternative hypothesis, that at least some individual does not have a unitary root, with $\mathrm{Ha}: \rho_{\mathrm{i}}<0$. In order to determine the numbers of lags in the test, the proce- dure used by Ng and Perron (1995) was used, and an upper limit of four lags was adopted.

The IPS test was carried out in two functional ways, with a constant and without a trend, and with a constant and with a trend, showing that the null hypothesis that all of the data series are not stationary was rejected with a $99 \%$ degree of certainty, as shown in Table 3.

Table 3 Unitary Root Test

\begin{tabular}{ccc}
\hline & \multicolumn{2}{c}{ IPS } \\
\hline Variable & With constant and without trend & With constant and with trend \\
\hline Buffer & -6.7307 & -4.3452 \\
& $(0.0000)$ & $(0.0000)$ \\
\hline
\end{tabular}

Note. $p$-value in brackets.

Source: Developed by the authors.

\subsection{Analysis of the Results}

The results found for the four models can be observed in Table 4. The cost of bankruptcy, represented by the Risk variable, exhibited a positive sign and a $1 \%$ degree of significance for all of the models. Its coefficient exhibited a small variation in models 1,2 , and 3 , and a greater variation in model 4, probably caused by the inclusion of more variables with bank risk profile characteristics. Based on the results found, it can be inferred that the Risk variable moved in the same direction as the capital buffers held by the banks.

Table 4 Estimation of GMM system model for capital buffers

\begin{tabular}{|c|c|c|c|c|c|c|c|c|}
\hline \multirow{2}{*}{$\begin{array}{l}\text { Variables } \\
\text { Buffer i,t-1 }\end{array}$} & \multicolumn{2}{|c|}{ Model 1} & \multicolumn{2}{|c|}{ Model 2} & \multicolumn{2}{|c|}{ Model 3} & \multicolumn{2}{|c|}{ Model 4} \\
\hline & 0.66 & $(0.00)$ & 0.66 & $(0.00)$ & 0.70 & $(0.00)$ & 0.59 & $(0.00)$ \\
\hline RoE i,t & 1.68 & $(0.00)$ & 1.63 & $(0.07)$ & 1.45 & $(0.00)$ & 1.74 & $(0.33)$ \\
\hline Risk i,t & 7.32 & $(0.00)$ & 6.85 & $(0.00)$ & 8.69 & $(0.00)$ & 4.72 & $(0.00)$ \\
\hline Size $i, t$ & -1.20 & $(0.00)$ & -1.23 & $(0.00)$ & - & - & -1.25 & $(0.00)$ \\
\hline Variation in GDP t & 0.00 & $(0.59)$ & - & - & - & - & 0.00 & $(0.27)$ \\
\hline Volatility i,t & - & - & - & - & - & - & -0.01 & $(0.90)$ \\
\hline Liquidity i,t & - & - & - & - & - & - & 12.87 & $(0.00)$ \\
\hline Weight of Portfolio i,t & - & - & - & - & - & - & 5.41 & $(0.05)$ \\
\hline Control i,t & - & - & - & - & - & - & 1.96 & $(0.69)$ \\
\hline Origin $\mathrm{i}, \mathrm{t}$ & - & - & - & - & - & - & 2.69 & $(0.02)$ \\
\hline Small Portfolio i,t & - & - & - & - & - & - & 0.37 & $(0.40)$ \\
\hline Basel II t & - & - & - & - & - & - & 0.58 & $(0.00)$ \\
\hline Large Banks i,t & - & - & - & - & -0.87 & $(0.01)$ & - & - \\
\hline Small Banks i,t & - & - & - & - & 1.73 & $(0.00)$ & - & - \\
\hline Constant t & 17.35 & $(0.00)$ & 17.85 & $(0.00)$ & 0.25 & $(0.01)$ & 9.62 & $(0.00)$ \\
\hline $\mathrm{AR}(1)$ & -2.25 & $(0.02)$ & -2.20 & $(0.03)$ & -2.22 & $(0.03)$ & -2.16 & $(0.03)$ \\
\hline $\operatorname{AR}(2)$ & -0.90 & $(0.37)$ & -0.94 & $(0.35)$ & -0.94 & $(0.35)$ & -0.96 & $(0.34)$ \\
\hline Sargan & \multicolumn{2}{|c|}{$\begin{array}{c}x^{2}(292)=119 \\
(1.00)\end{array}$} & \multicolumn{2}{|c|}{$\begin{array}{c}x^{2}(292)=118 \\
(1.00)\end{array}$} & \multicolumn{2}{|c|}{$\begin{array}{c}X^{2}(292)=118 \\
(1.00)\end{array}$} & \multicolumn{2}{|c|}{$\begin{array}{c}X^{2}(291)=115 \\
(1.00)\end{array}$} \\
\hline
\end{tabular}

Note. $p$-value in brackets.

Source: Developed by the authors.

The size of banks, represented by the Size variable, exhibited a negative sign and a $1 \%$ degree of significance for all of the models. For this variable, there was practi- cally no variation in its estimated coefficients. The result was as expected, making it possible to infer that the larger banks held smaller capital buffers. 
The dummy variable Large Bank exhibited a negative sign and a $1 \%$ degree of significance. The dummy variable Small Bank exhibited a positive sign and was also significant to a degree of $1 \%$. The negative sign found for the dummy variable Large Bank is consistent with the sign found for the Size variable in models 1, 2, and 3, showing that the banks which comprised the largest $10 \%$ in terms of total assets held smaller capital buffers. The result found for the dummy variable Small Bank shows a complementary characteristic to the result found for the Size variable in models 1,2 , and 3 , in which the small banks held larger capital buffers during the period.

The economic cycle, represented by the Variation in GDP variable, exhibited a positive sign, but was not significant for all of the models. Analyzing its sign alone, a positive sign would show that the economic cycle has a counter-cyclical behavior, and that an increase in capital buffers is to be expected during economic growth, or oppositely, a reduction in capital buffers during an economic recession. As the coefficient found for the variable was very close to zero, its $95 \%$ confidence interval varied between positive and negative values. Thus, the results analysis for this variable was inconclusive, meaning it was not possible to make any inferences regarding the behavior of the economic cycle being pro-cyclical or counter-cyclical.

The Variation in Credit variable exhibited a negative sign and a $1 \%$ degree of significance in all of the models, and its estimated coefficients remained practically unaltered. The result was as expected, given that an increase in the number of credit operations causes an increase in bank assets weighted by risk, providing evidence of movement in the opposite direction to the capital buffer variable.

The Volatility variable exhibited a negative sign, but was not significant to a $5 \%$ level of confidence. The sign found for this variable was the opposite to that expected, since it foresees that banks increase their capital buffers through retained earnings, given that the existence of high volatility in results would mean they were unable to rely on this source of funds, and need to hold larger capital buffers. The result found can be interpreted as the effect of volatility on banks' ability to retain earnings, given that volatility in results does not allow for the incorporation of earnings into the composition of their capital buffers. As the result for the variable was highly non significant $(0,90)$, the analysis of its results was inconclusive.

The Liquidity variable exhibited a positive sign and was significant to a degree of $1 \%$. The sign found for this variable was as expected, since the assets that compose it have little or no risk weighting. Another conclusion that can be inferred is that the fund raising carried out by banks, as a way of anticipating their capital needs, should have been applied in these liquid assets, given the impossibility of investing these funds in credit operations, at the time they are raised.

The Weight of Portfolio variable exhibited a positive sign and was significant to a degree of $5 \%$. This variable is related to cost of bankruptcy for banks, demonstrating their risk profile. From the result found, it is inferred that the banks that apply a higher percentage of their assets in credit operations held larger capital buffers to cope with the underlying risk of their operations, with this variable being an ex ante measure of risk for Brazilian banks.

The dummy variable Control exhibited a positive sign, but was not significant to a degree of $10 \%$. The sign exhibited by the variable shows that the banks controlled by public federal and state institutions held larger capital buffers than the banks controlled by private institutions. Given the non significance of the variable, the analysis of it was inconclusive.

The dummy variable Origin exhibited a positive sign and was significant to a degree of 5\%. The sign of the variable was the result that was expected. This result makes it possible to infer that, as the Basel II principles were implemented by foreign countries a longer time ago, their managers behaved more actively with regards to risk and capital management, in adherence to the Pillar II concepts of Basel II.

The dummy variable Mergers exhibited a negative sign, but was not significant to a degree of $10 \%$. The sign of the variable was compatible with what was expected, since it is assumed that the banks that took part in merger and/or acquisition processes had an increase in their assets weighted by risk, thus consuming their capital buffers. As the result was highly non significant, the analysis of the variable was inconclusive.

The dummy variable Small Portfolio exhibited a positive sign, but was not significant to a degree of $10 \%$. The sign of the variable was as expected, but its analysis was inconclusive.

The dummy variable Basel II exhibited a positive sign and was significant to a degree of $1 \%$. The sign of the variable was as predicted. This result allows it to be inferred that, with the adoption of the Basel II accord in Brazil, the banks implemented and streamlined their risk and capital management models, resulting in higher solvency monitoring, and, consequently, higher capital buffers being held.

\section{FINAL REMARKS}

This study sought to analyze the adequacy of the determining factors, proposed by the international literature, for holding regulatory capital buffers, for the reality for Brazilian banking institutions. The analysis comprised 121 banks and covered the period between 2001 and 2011. 
The international literature indicates adjustment cost, cost of holding capital, and bankruptcy cost as the main factors that determine capital buffers held. As well as these factors, the literature also mentions secondary factors such as size, economic cycle, and certain control variables.

With an aim to investigating whether such factors would be related to capital buffers being held in the case of Brazilian banks, an econometric model was formulated that was tested in four different ways, all composing dynamic data panels.

The result for the Adjustment Cost variable indicated a positive sign and significance in all of the models. The result found shows that, for the period analyzed, Brazilian banks exhibited high capital adjustment costs, with no great variations in capital between periods.

The RoE variable, describing the cost of holding capital, exhibited a positive sign, despite not being significant in all of the models, indicating that higher returns on capital can be used to increase banks' capital buffers. As the sign exhibited by the variable was positive in this study, it was not a good proxy for representing the cost of holding capital, which should exhibit a negative sign.

Cost of bankruptcy also exhibited statistical significance for the Brazilian banks through the variables that were used as proxies - Risk (ALLL/credit portfolio), Liquidity (financial investments/total assets), and Weight of Portfolio (credit portfolio/total assets). The result showed that the Brazilian banks' capital buffers moved in the same direction as the risk profile of their operations, increasing capital buffers when there is a greater risk profile, as expected.

With regards to size, it can be observed that the bigger the bank, the smaller its capital buffer, as was expected and consistent with the better investments and portfolio diversification hypothesis, and with the "too big to fail" hypothesis. The dummy variables Large Bank and Small Bank also showed that the largest banks held lower capital buffers and the small banks held larger capital buffers.

With relation to the economic cycle (variation in GDP), the results did not allow it to be stated whether behavior was pro-cyclical or counter-cyclical, given the non significance of the results. With relation to demand for credit (Variation in Credit Portfolio), an inverse relationship was observed, indicating that the more credit was granted, the lower the buffer was, as was expected. This showed that the banks did not raise sufficient funds to cope with the risks of these new operations, which caused a reduction in their capital buffers.

For the qualitative variables Control and Small Portfolio, it was not possible to draw any conclusions regarding their results, due to the non significance of them. With relation to the Origin variable, it was shown that the foreign banks held larger capital buffers than the Brazilian banks, as was expected, suggesting the possibility of foreign managers behaving more actively with regards to managing their capital.

With relation to the occurrence of mergers and acquisitions, a reduction in capital buffers was expected. The sign found was consistent with that expected, but without it being conclusive, given the non significance of the Mergers variable.

For the Basel II variable it is inferred that with the implementation of the Basel II accord, the banks came to hold a higher level of capital buffers, verified by the implementation and streamlining of risk and capital management models, resulting in greater monitoring of their solvency.

This paper contributes to studies of factors that influence the determining of banks' capital buffers, seen to be a poorly studied issue, mainly with regards to Brazilian banks. Moreover, the study also contributes to the field of Accounting and financial markets, assisting in understanding the structure of capital held by the banking sector, a segment that is generally excluded from studies focused on capital structure.

For future studies, it is suggested that a proxy be found that better represents the cost of holding capital, given that the RoE variable does not exhibit a sign that is compatible with the theory, in the case of Brazilian banks. It is also suggested that other variables related with the risks that banks are exposed to be used. This study focused specifically on credit risk, which is the biggest component of the risk banks are subject to, but other risks can also cause an impact on the holding of capital buffers.

\section{References}

Alencar, L. S. (2011). Um exame sobre como os bancos ajustam seu Índice de Basileia no Brasil [Trabalho para discussão $\mathrm{n}^{\circ} 251, \mathrm{p}$ 1-22]. Banco Central, Brasília, DF.

Araújo, L. A. D., Jorge, P. M., Neto, \& Linhares, F. (2008). Capital, risco e regulação dos bancos no Brasil. Pesquisa e Planejamento Econômico, 38(3), 459-486.

Arellano; M., \& Bond, S. (1991). Some tests of specification for panel data: Monte Carlo evidence and an application to employment equations. The Review of Economic Studies, 58(2), 277-29.7.

Arellano, M., \& Bover, O. (1995). Another look at the instrumental variable estimation of error-components models. Journal of econometrics, 68(1), 29-51.

Ayuso, J., Perez, D., \& Saurina, J. (2004). Are capital buffers procyclical? Evidence from Spanish panel data. Journal of Financial Intermediation, 13(2), 249-264.

Banco Central do Brasil (2012). Relatório de Estabilidade Financeira, 11(1). Retrieved on July 01, 2012, from http://www.bcb.gov. br/?RELESTAB201203.

Baltagi, H. B. (2008). Econometric Analysis of Panel Data (4th ed.). Chichester, West Sussex: John Wiley \& Sons Ltd. 
Berger, A. N., Herring, R. J., \& Szegö, G. P. (1995). The role of capital in financial institutions. Journal of Banking \& Finance, 19(3) $393-430$.

Bikker, J. A., \& Metzemakers, P. A. J. (2007). Is bank capital procyclical? A cross-country analysis. Kredit und Kapital, 40(2), 225-264.

Blundell, R. W., \& Bond, S. R. (1998). Initial conditions and moment restrictions in dynamic panel data Models. Journal of Econometrics; 87(1), 115-143

Boucinha, M., \& Ribeiro, N. (2007). Determinantes do excesso de capital dos bancos portugueses. Relatório de Estabilidade Financeira, Banco de Portugal. Lisboa.

Conselho Monetário Nacional (1999). Resolução n 2.682, de 21 de dezembro de 1999. Retrieved on June 9, 2012 from http://www. bcb.gov.br/pre/normativos/busca/normativo.asp?tipo=res\&ano=19 998numero $=2682$

Elizalde, A., \& Repullo, R. (2007). Economic and regulatory capital in banking: What is the difference? International Journal of Central Banking, 3(3), 87-117.

Estrella, A. (2004). The cyclical behavior of optimal bank capital Journal of Banking \& Finance, 28(6), 1469-1498.

Ferreira, R. A., Noronha, A. C., Tabak, B. M., \& Cajueiro, D. O. (2010). O comportamento cíclico do capital dos bancos brasileiros. Revista Economia, 11(3), 671-690.

Fonseca, A. R., \& González, F. (2010). How bank capital buffers vary across countries: The influence of cost of deposits, market power and bank regulation. Journal of Banking \& Finance, 34(4), 892-902.

Glantz, M (2007). Gerenciamento de riscos bancários: introdução a uma ampla engenharia de crédito. Rio de Janeiro: Elsevier.

Gropp, R., \& Heider, F. (2010). The determinants of bank capital structure. Review of Finance, 14(4), 587-622.

Im, K. S., Pesaran, M. H., \& Shin, Y. (2003). Testing for unit roots in heterogeneous panels. Journal of econometrics, 115(1), 53-74.

Jokipii, T., \& Milne, A. (2008). The cyclical behaviour of European bank capital buffers. Journal of Banking \& Finance, 32(8), 1440-1451.

Jokipii, T., \& Milne, A. (2011). Bank capital buffer and risk adjustment decisions. Journal of Financial Stability, 7(3), 165-178.

Lindquist, K. G. (2004). Banks' buffer capital: how important is risk. Journal of International Money and Finance, 23(3), 493-513.

Medeiros, O. R., \& Pandini, E. J. (2007). Índice de Basileia no Brasil: bancos públicos x privados. Revista de Educação e Pesquisa em Contabilidade (REPeC), 1(2), 22-42.

Mehran, H., \& Thakor, A. (2011). Bank capital and value in the crosssection. Review of Financial Studies, 24 (4), 1019-1067.

Myers, S. C. (1984). The capital structure puzzle. Journal of Finance, 39(3), 575-592.

Ng, S., \& Perron, P. (1995). Unit root tests in ARMA models with datadependent methods for the selection of the truncation lag. Journal of the American Statistical Association, 90(429), 268-281.

Peura, S., \& Keppo, J. (2006). Optimal bank capital with costly recapitalization. The Journal of Business, 79(4), 2163-2201.

Rime, B. (2001). Capital requirements and bank behaviour: Empirical evidence for Switzerland. Journal of Banking \& Finance, 25(4), 789-805.

Shrieves, R. E., \& Dahl, D. (1992). The relationship between risk and capital in comercial banks. Journäl of Banking \& Finance, 16(2), 439-457.

Silva, M. S. da, \& Divino, J. A. (2012). Determinantes do capital excedente na indústria bancária brasileira. Pesquisa e Planejamento Econômico, 42(2), 261-293.

Stolz, S., \& Wedow, M. (2011). Banks' regulatory capital buffer and the business cycle: Evidence for Germany. Journal of Financial Stability, 7(2), 98-110.

Tabak, B. M., Fazio, D. M., \& Cajueiro, D. O. (2011). The relationship between banking market competition and risk-taking: do size and capitalization matter? [Trabalho para discussão no 261, p. 1-42] Banco Central, Brasília, DF

Tabak, B. M., Li, D. L., Vasconcelos, J. V. L., \& Cajueiro, D. O. (2013) Do capital buffers matter? A study on the profitability and funding costs determinants of the Brazilian banking system [Trabalho para discussão no 333, p. 1-36]. Banco Central, Brasília, DF.

Tabak, B. M., Noronha, A. C., \& Cajueiro, D. O. (2011). Bank capital buffers, lending growth and economic cycle: empirical evidence for Brazil [Working Paper $n^{\circ} 4$ ]. Banking for International Settlements, Basel, Switzerland.

Vallascas, F., \& Hagendorff, J. (2013). The risk sensitivity of capital requirements: evidence from an international sample of large banks. Review of Finance, 17(6), 1947-1988.

Windmeijer, Frank. (2005). A finite sample correction for the variance of linear efficient two-Step GMM estimators. Journal of Econometrics, 126(1), 25-51.

\section{Correspondence Address:}

\section{Vinícius Cintra Belém}

Banco do Brasil

SBS Ed. Sede III - $17^{\circ}$ andar - CEP: 70.073-901

Brasília - DF - Brasil

Email: vinicius.cintra@gmail.com 